\title{
Słowo wstępne: \\ Czym są i czym nie są naukowe badania szkolnictwa wyższego
}

„Nauka i Szkolnictwo Wyższe” to pismo naukowe mogące się poszczycić wspaniałą historią. Od $1993 \mathrm{r}$. funkcjonuje nieprzerwanie nie tylko jako miejsce dyskusji o najważniejszych problemach nauki i szkolnictwa wyższego, ale również jako instytucja, dzięki której polscy badacze prezentują wyniki swoich najnowszych badań. Jako Centrum Studiów nad Polityką Publiczną UAM jesteśmy niezwykle dumni z faktu, że możemy kontynuować pracę wydawniczą zapoczątkowaną przez warszawski zespół prof. Ireneusza Białeckiego (któremu jesteśmy szczerze wdzięczni za pozostanie w Radzie Naukowej pisma).

Dziś, gdy instytucja uniwersytetu znalazła się w samym centrum dyskusji dotyczących społecznego i gospodarczego rozwoju nowoczesnych społeczeństw, teoretyczny namysł i empiryczne badania jej przekształceń mają znaczenie większe niż kiedykolwiek wcześniej. Bardzo trudno jednak ujmować jej transformacje w oderwaniu od transformacji, jakim poddawana jest cała tkanka społeczna, w której uniwersytet jest osadzony. Nowoczesny uniwersytet - podobnie jak, szerzej, całe szkolnictwo wyższe - podlega dzisiaj bowiem dokładnie takim samym presjom jak inne nowoczesne instytucje społeczne. Dzieje się tak na całym świecie, również w Polsce. Uważamy, że w tej sytuacji istotnego znaczenia nabierają zwłaszcza międzynarodowe badania porównawcze szkolnictwa wyższego.

Chcielibyśmy, aby przyjmowane do druku teksty prezentowały podejście dyscyplinarne i metodologiczne związane z naukowymi badaniami szkolnictwa wyższego (czyli higher education research). W polskim kontekście duże znaczenie ma koncentracja na drugim członie tego określenia, a mianowicie research. Zamierzamy publikować tutaj wyniki badań naukowych - podobnie jak przez ostatnie dwie dekady funkcjonowania pisma - a nie akademickie polemiki. Chociaż pola 
badawcze zajmowane przez ten obszar wiedzy w świecie są dosyć ściśle zdefiniowane, a same badania mają rozległą tradycję teoretyczną, w Polsce ta subdyscyplina nauk społecznych (oraz nauk o polityce publicznej) - w wersji znanej w krajach Europy Zachodniej - dopiero zaczyna się rozwijać. Ma jednak bogatą tradycję w Polsce powojennej, do której warto nawiązywać.

W związku z tak określoną rolą pisma publikowane teksty nie będą brać udziału w publicystycznych dyskusjach, polskich czy międzynarodowych - chociaż być może do tych pierwszych będą się pośrednio przyczyniać. Nie będą też bezpośrednio odpowiadać na bieżące problemy szkolnictwa wyższego. Naturalnym odbiorcą publikacji z obszaru badań szkolnictwa wyższego jest wspólnota badawcza, która tym obszarem świata społecznego zajmuje się naukowo i zawodowo. Odbiorcami pisma mogą być również, rzecz jasna, naukowcy zajmujący się badaniami szkolnictwa wyższego jedynie okazjonalnie, z perspektywy swoich dyscyplin, oraz - jak w całym świecie - tzw. refleksyjni praktycy. Mogą też być nimi naukowcy, których interesują transformacje szkolnictwa wyższego w Polsce, Europie i na świecie; lub w Polsce - w kontekście Europy i świata.

Badania szkolnictwa wyższego mają swoją tradycję, swoich najczęściej czytanych autorów i swoje uznane metodologie, sieć najlepszych nazwisk i najbardziej uznanych czasopism międzynarodowych. To jeden z najbardziej zinternacjonalizowanych obszarów nauk społecznych w Europie. Jak w każdej wyłaniającej się subdyscyplinie naukowej istnieje hierarchia jej ojców założycieli, hierarchia najlepszych autorów piszących dzisiaj i wyłaniająca się hierarchia najbardziej obiecującego naukowo młodego pokolenia. Niemal nie da się jej uprawiać w ujęciu czysto krajowym - chociaż badania krajowe są jej niezbędną częścią; to obszar nauki poniekąd stworzony do badań porównawczych i do szeroko zakrojonej współpracy międzynarodowej. Ich tradycja sięga z grubsza lat 50. ubiegłego wieku w USA, a charakteryzuje ją historia walki o uznanie odrębności przez przedstawicieli innych dyscyplin w naukach społecznych. W badaniach szkolnictwa wyższego toczą się nieustanne zmagania o akademickie uznanie, teoretyczną dominację, pierwszeństwo odkrycia czy pierwszeństwo zaproponowania najbardziej użytecznych ram teoretycznych. Mają one również swoją dramatyczną historię uniezależniania się od polityki i polityki naukowej, od ujęcia czysto utylitarnego, rozpowszechnionego dzisiaj zwłaszcza w USA (ale już nie w Europie Zachodniej). Badania te muszą stale walczyć o zachowanie równowagi między ważnością społeczną i ekonomiczną (czyli praktycznością swoich wyników) a naukową doskonałością (i teoretycznością): między social relevance i academic excellence. Rozpięte między tymi dwoma imperatywami, jednocześnie żadnemu z nich nie mogą ulec w całości jeśli chcą samodzielnie przetrwać.

Badacze szkolnictwa wyższego muszą często stawiać mury obronne między praktycznymi badaniami prowadzonymi na rzecz rządów i instytucji akademickich, w tym instytucji macierzystych, a badaniami ściśle naukowymi o aspira- 
cjach teoretycznych. Z jednej strony muszą być naukami podstawowymi, z drugiej - muszą odwoływać się do otaczającego świata gospodarczego i społecznego. Granica między nimi jest często w praktyce niezwykle cienka, ponieważ badania szkolnictwa wyższego (zwłaszcza porównawcze i empiryczne) wymagają dużych nakładów publicznych, ale granica ta musi być wyraźnie zaznaczona. Problemy tożsamości tej subdyscypliny częściowo wynikają z faktu, że jest ona dzisiaj niezwykle potrzebna. Zapotrzebowanie na wyniki jej badań - zarówno teoretycznych, jak i praktycznych - jeszcze nigdy w historii ostatnich kilku dekad nie było tak duże jak obecnie; nigdy przedtem nie były one też tak szeroko komentowane poza obszarem akademii, co wiąże się z dużą odpowiedzialnością społeczną.

Naukowe badania szkolnictwa wyższego to nie refleksje rektorów czy dziekanów, nawet najbardziej zasłużonych, dotyczące funkcjonowania uczelni; nie są to również prace prowadzone poniekąd z doskoku, przez przedstawicieli różnych dyscyplin na marginesie ich głównych zainteresowań naukowych. Publicystyczne i praktyczne głosy wspólnoty akademickiej są niezwykle ważne, m.in. z politycznego i socjologicznego (a z czasem historycznego) punktu widzenia, ale nie przyczyniają się do narastania wiedzy o szkolnictwie wyższym. Badania naukowe są zatem w tym sensie a full-time job i wymagają pełnej koncentracji badawczej, podobnie jak we wszystkich innych obszarach nauki. Amatorskie, a więc dodatkowe i w tym sensie trochę przypadkowe, zajmowanie się szkolnictwem wyższym jest przydatne $\mathrm{w}$ dyskursie publicznym (oraz $\mathrm{w}$ ramach polityki publicznej) - przydaje się w pracach nad strategiami rozwoju szkolnictwa wyższego, jego reformami i regulującymi je prawami, ale z badaniami szkolnictwa wyższego, tak jak je tutaj rozumiemy (za międzynarodową społecznością naukową), mają one niewiele wspólnego. Dopóki w myśleniu o szkolnictwie wyższym nie będziemy widzieć dominującego pierwiastka naukowego i teoretycznego, dopóty pokutować będzie - zasadniczo nieznane poza postkomunistyczną Europą - przekonanie, że o nauce i szkolnictwie wyższym powinni wypowiadać się amatorzy. Nasze pismo będzie koncentrować się na badaniach naukowych.

Dużym wyzwaniem dla tego typu badań jest świadomość, że przecież de nobis fabula narratur: opowiadamy o nas samych, czyli badacze zajmują się strukturami, procesami, instytucjami i normami, w ramach których sami funkcjonują. Badając struktury zastane, ale i projektując przyszłe struktury, nie można, jak się wydaje, pochodzić z radykalnie innej kultury niż kultura akademicka. Z pewnością nie udawało się jak dotąd podchodzenie do badań uniwersytetu z perspektywy kultury biznesu czy kultury polityki, czyli badanie instytucji uniwersytetu poniekąd z zewnątrz. O uniwersytecie pisali w XX wieku przede wszystkim historycy, socjologowie, ekonomiści, filozofowie, politolodzy, badacze organizacji, zarządzania i edukacji. Jednak od ok. 20-30 lat badania szkolnictwa wyższego w świecie coraz bardziej się profesjonalizują. W Europie kilka tysięcy naukowców zajmuje się w swoich badaniach wyłącznie funkcjonowaniem szkolnictwa wyższego, po- 
wstają ukierunkowane programy magisterskie i doktoranckie, a na dorocznych spotkaniach najważniejszych stowarzyszeń naukowych (takich jak EERA, SRHE czy EAIR) pojawia się regularnie od tysiąca do kilku tysięcy badaczy.

„Nauka i Szkolnictwo Wyższe” jest jedynym czasopismem, w którym systematycznie publikowała polska odnoga międzynarodowej wspólnoty badaczy szkolnictwa wyższego. Do tego zadania będziemy nadal nawiązywać. Zebrane w niniejszym numerze teksty to pokłosie wystąpień na I Ogólnopolskiej Konferencji Badaczy Szkolnictwa Wyższego, zorganizowanej przez Centrum Studiów nad Polityką Publiczną UAM w czerwcu 2015 r. w Poznaniu. Choć ich przekrój tematyczny i wachlarz stosowanych metod badawczych jest szeroki, łączy je jedno: naukowy wysiłek mający na celu wyjaśnianie istotnych problemów, z jakimi mierzy się współcześnie sektor szkolnictwa wyższego w Polsce i na świecie. Serdecznie zapraszamy Państwa do lektury, a także do przysyłania tekstów do kolejnych numerów!1

Wimieniu redakcji prof. dr hab. Marek Kwiek

CYTOWANIE: Kwiek, M. (2015). Słowo wstępne: Czym są i czym nie są naukowe badania szkolnictwa wyższego. Nauka i Szkolnictwo Wyższe. 1(45): 7-10. DOI: 10.14746/nsw.2015.1.o.

${ }^{1}$ Podziękowania: wspomniana konferencja nie odbyłaby się bez wsparcia udzielonego przez Narodowe Centrum Nauki (NCN) w ramach projektu MAESTRO (Program Międzynarodowych Badań Porównawczych Szkolnictwa Wyższego DEC-2011/o2/A/HS6/o0183, 2012-2017), a prezentowany numer pisma nie ukazałby się bez wsparcia udzielonego przez NCN oraz przez Fundację na Rzecz Nauki Polskiej (FNP) w ramach projektu MISTRZ (subsydium profesorskie - umowa 5/2015, 20162018). Wyrażam niniejszym swoją głęboką wdzięczność obydwu instytucjom. 